\title{
INTERIM MEASURES FOR SECURING THE CLAIM IN CIVIL PROCEEDINGS IN KOSOVO: LEGAL AND PRACTICAL ASPECTS
}

\author{
Haxhi XHEMAJLI \\ E-mail: haxhi.xhemajli@student.um.si \\ Ma.Sc. LL.M. PhD student \\ University of Maribor, Faculty of Law, Slovenia
}

\begin{abstract}
The primary aim of interim measures is to preserve the rights and interests of the parties in civil litigation. The Law on Contested Procedure enumerates two types of measures designed to safeguard the rights of each party, and to preserve the court's ability to render a meaningful judgement in the litigation. The measures provided in the law are categorized into two groups: security measures and interim measures. Although both measures share some similarities, judicial practice has revealed a number of nuanced differences that make each distinctly unique. As a result, courts tend to frequently apply interim measures as a legal mechanism for preventing any irreparable harm or loss to a party before the final judgement on the merits of the case is rendered. An additional element that brought some opposing views among the members of the judiciary, is the right to use legal remedies. This paper will analyze disparities in application of the measures, discuss the legal framework for such application and examine recent judicial practice regarding the use of legal remedies.
\end{abstract}

Key words: security measures; interim measures; claim; Law on Contested Procedure; plaintiff; judicial practice; defendant; legal remedies.

\section{Introduction}

In civil proceedings, the role of the courts is to provide adequate protection of the rights and interests of the litigants. One of the legal mechanisms for preserving the rights and interests of the parties in civil litigation is the institution of interim measures. The main purpose of these 
measures is to prevent any irreparable harm or loss before the final judgment on the merits of the case is rendered. The current legal framework has recognized two types of measures the litigants may request in civil proceedings: (1) security measures and (2) interim measures.

The Law on Contested Procedure as a main legal act governing civil procedure in Kosovo has brought some changes by introducing a slightly different system of application of the interim measures. Due to the newly integrated system of measures, judicial practice has shown that the litigants more frequently request from the courts the imposition of the second group of measures (interim measures). The reason for seeking the imposition of interim measures is related to cases where the threat of irreparable harm is immediate and the need to preserve the status quo is urgent. Additionally, interim measures are issued ex parte without notification or a preliminary hearing, whereas security measures are issued inter partes, with a hearing by the court and allowing both parties the opportunity to express their opinions on the matter. Considering that their urgent nature is aimed at protecting the rights and interest of the parties involved in civil litigation, these measures are mostly requested in cases involving property disputes, and intellectual property cases. In this respect, the courts act promptly and without delay in order to provide appropriate protection of the rights of the litigants who have requested such measures.

As we will discuss, the distinction between security measures and interim measures in the process of securing a claim is quite obvious. Judicial practice also, to some extent, varies with regard to the application of legal remedies. This paper will provide an overview of the legal framework for imposing interim measures in civil proceedings, discuss the legal requirements for granting them, and examine the recent developments in judicial practice concerning the application of these legal remedies.

\section{Legal Framework for Interim Measures}

The rules for securing the claim in civil proceedings are enshrined in the provisions of the Law on Contested Procedure (art. 296 - 318; henceforth "LCP"). The LCP contains provisions that regulate two types of measures for securing the claim in three distinct types of civil proceedings. Therefore, as we will elaborate infra, these two legal measures for securing the claim are: (1) security measures and (2) interim measures (art. 296(1) and 306(1) LCP). Prior to the LCP, these measures were included in the provisions of the former Law on Executive Procedure (Official Gazette of SFRY, No. 20/1978) which was replaced by the new Law on Enforcement Procedure in 2008 (Official Gazette, No. 33/15 July 2008).

In 2012, the new Law on Enforcement Procedure (Official Gazette, No. 3/31 January 2013, (henceforth: "LEP") was enacted, which repealed the previous legal acts in this field, including the Law on Executive Procedure (Official Gazette, No. 33/15 July 2008). With the entry into force of the LCP, the legislature has introduced some novelty by recognizing that the 
application for securing the claim should be done in the contested procedure by the court which acts according to the claim in the first instance. The intention of the law is, however, to equip those who apply for security measures with the legal mechanisms against the other party (defendant) whose intention is to make recognition of the rights of the plaintiff impossible.

It is important to stress that, security measures appear to function as a necessary instrument in the administration of justice (Westberg, 2012, p. 539). According to the provisions of the LCP, the applicant acts by presenting credible arguments that the opposing party will act improperly by alienating, hiding, encumbering or disposing of the applicant's assets. Thus, the applicant reacts by parrying the imminent threat immediately (Westberg, 2012, p. 539), through the filing of the application to impose the security measures with the courts. Finally, with regard to the terminology, the LCP has retained the term "the party proposing security measures" and the "objector of the measures." However, both these terms are equivalent to the common terms used in civil litigation such as plaintiff and defendant. In the following, we will use the terms as plaintiff instead of the party proposing security measures, and defendant as a substitute for the term objector of the measures.

\section{Legal Nature}

The LCP does not clearly define the nature of the security measures, as both measures for securing the claim are temporary and last until the final judgment is rendered by the court. Accordingly, as foreseen in chapter XXI of the LCP, security measures in their legal nature, are interim measures (Morina \& Nikçi, 2012, p. 542), intending to preserve a factual or legal situation without a res judicata effect as to the merits of the case. Since most applications for such measures are requested in property disputes, however, civil courts primarily impose these measures as interim measures due to the urgency need to protect a certain right.

Furthermore, in legal terminology we may find them referred to as "provisional measures," "conservatory measures," "preliminary injunctions," or "interim relief." Regardless of the terminology, their characteristics are linked to their temporary nature whose sole aim is to avoid unjust results before the final judgments are rendered (Atlihan, 2011, p. 204). Although the legislator has not made clear the nature of these measures, they typically take the form of an injunction restraining a party from disposing of or otherwise dealing with his or her assets while judgment on the merits of the case is pending (OSCE, 2010). It is worth mentioning here that the distinction between security measures and interim measures is based on certain criteria, circumstances and elements that courts consider when it comes to reviewing the applications for imposing these measures. However, the common feature of these measures is their temporary nature, functioning as a legal mechanism for protecting the rights and interest of the parties involved in civil litigation until the final judgment on the merits of the case is reached by the court. 


\section{Types of Measures and Conditions for Imposing them in Civil Proceedings}

As has been noted above, the LCP recognizes two types of measures applied in three distinct types of civil proceedings, involving (1) monetary claims, (2) claims for specified assets, and (3) claims for securing the rights and preserving existing circumstances (art. 299, 300, 301 LPC).

\subsection{Security Measures Involving Monetary Claims}

Pursuant to provisions of the art. 299(1)(a) of the LCP, the court may impose these measures in order to prohibit the defendant from alienating, hiding, indebting or holding wealth up to a sufficient amount for securing the claim. Furthermore, it is of significant importance that the plaintiff, for purposes of restraining the defendant from undertaking the above-actions to register his rights in the property rights register. Such measures serve as a legal tool to prevent the defendant from further reducing the wealth that is meant to be used for the purposes of securing the claim. This situation implies that any actions taken by the defendant with the intent to contradict the effects of such measure will be considered invalid and have no legal effect.

However, an amount sufficient to satisfy the claim (OSCE, 2010), could either deposited with the court, left in the plaintiff's possession, or given to a third party (art. 299(1)(b) LPC). Accordingly, this amount should be used consistent with the intended purpose of securing the claim, and not be used by either party. In the process of preserving the value for securing the claim, the court has an active role in providing adequate measures in this respect. But, if the court cannot provide the appropriate conditions for securing this amount, then the amount could be entrusted to either the plaintiff or if the plaintiff is unwilling to secure the wealth, to a third person (Morina \& Nikçi, 2012, p. 548). Among the items for securing the claim are movable assets that can be damaged easily or whose value could drop significantly. In this regard, the LCP can resolve this situation by recognizing the opportunity of selling these items. This situation provides certain features that include inter alia the right of the defendant or third party to propose the sale of such items (art. 311(1) LCP). The sale of such assets has to be conducted in compliance with the provisions of art. 99 of the LEP. In its provisions, the LEP stipulates the method which must be followed in order to conduct the sale (either through verbal public auction, or direct settlement between the purchaser, in one side and the enforcement body, or other authorized subject in other side) of the items the court has decided need to be sold, due to the fact that they could be easily damaged or if there is a risk of a fall in price. The LCP imposes a restrain towards the debtor of the defendant. In this situation, the debtor of the defendant is obliged not to perform certain action that could culminate in the fulfillment of the defendant's request or delivering a good (art. 299(1)(c) LCP). This also restrains the activities of the defendant. Therefore, the 
defendant should refrain from receiving and possessing the good, and fulfilling his request.

This is not to say that the aforementioned legal requirements are the only measures for securing monetary claims. Quite to the contrary, the LCP recognizes the right of a pre-registration of a mortgage against the defendant's real property. The LCP does require some conditions be met in order for this measure to be imposed, such as having a judgment which is not yet enforceable (art. 299(1)(d). Preregistration extends only to the amount of the main request, including interests and procedural spending for which the final judgment has been rendered. These four measures for securing the monetary claims enlisted in this category, along with the measures for securing the claim for specified assets are numerus clausus as set down in the provisions of the law. There is a difference to the third category of security measures (e.g., securing the rights and preserving existing circumstances.) As provided in the law, this group of measures is not numerus clausus, as the civil court may impose other measures if considers necessary to adequately secure the plaintiff's request (art. 300(1)(d) LCP). With regard to the application, current judicial practice is more oriented toward the application of the second group of security measures, interim measures (Zogaj et al. 2019, p. 205). The following brief analysis will indicate how this group of measures is more often imposed by the courts in the form of interim measures.

\subsection{Security Measures Involving Claims for Specified Assets}

Provisions of the LCP authorizes imposition of the measures in cases involving claims for specified item or a part of it. First and foremost, the purpose of these measures is to forbid the defendant to alienate, hide, indebt or hold the assets toward which the plaintiff's request is directed (art. 300(1)(a) LCP ). As mentioned, the goal of the interim measures is to preserve the status quo, on the view that without the interim measures, it becomes difficult sometimes virtually impossible, for a court (Friedenthal et al. 2013, p. 1137) to accomplish its mission in civil litigation, that is to secure the enforcement of the future judgment expected to be given in favor of the plaintiff (Westberg, 2012, p. 541).

Thus, pursuant to LCP, an interim measure is meant to be an exceptional measure as the courts applies it only when certain legal requirements are fulfilled by the plaintiff who requested such measures (art. 306(1). When dealing with applications for granting interim measures, courts must be given sufficient evidence that a certain request is urgent and adequately justified. The plaintiff has the burden of proof, when there is an application for granting an interim measure and this is a constituent element of this provision. But what exactly are the legal requirements for granting interim measures? The LCP, explicitly requires some special conditions. First, the plaintiff must prove that his request for interim measures is based and urgent. Second, the plaintiff must provide also that an irreparable harm is likely to occur and the aim of such measure would be lost if not acted upon with urgency. Rather, 
from the perspective of judicial practice, interim measures are most frequently requested in property related disputes, and these measures include (1) disturbance of possession; (2) forbidding the defendant from alienating the immovable property; (3) forbidding the defendant from leasing the immovable; and (4) encumbering the property with a mortgage. The court forbids the defendant from performing specified action that will result in alienation, or encumbering with mortgage immovable property (Case, C. No. 228/13). ${ }^{1}$ In cases involving disturbance of possession, the courts usually imposes interim measures by ordering the defendant to cease further actions in relation to the specified asset (e.g., to stop constructing, digging or continuing the construction) (Case, C. No. 3280/13). But, to impose one of the above interim measures, courts strictly assess the evidence submitted by the plaintiff. Therefore, the plaintiff must satisfy the legal conditions set out in the law, for example, making his request plausible, based and urgent and also establishing that acting otherwise will inevitably result in irreparable damage (Case, C. No. 675/12). After receiving evidence that the plaintiff's right has been or is likely to be infringed by the defendant (Kamilovska, 2013, p. 6), and that the irreparable damage is imminent, the court concludes by providing protection for the requesting plaintiff by imposition of the interim measures.

Interim measures bear some distinctive features comparing to security measures, as interim measures are issued ex parte without a notification or a preliminary hearing of the defendant (art. 306(1) LCP). An interim measure which is issued ex parte, is appropriate only when the threat of irreparable harm is immediate and the need to preserve the status quo is urgent (Friedenthal et al. 2013, p.1138). In cases where ex parte interim measures are ordered, the court will deliver the decision to the defendant (Kamilovska, 2013, p. 10). Upon receiving the decision, the defendant is granted the right to object to the conclusions reached and the interim measures within three days by asking for the decision to be annulled or replaced (art. 306(2)(3) LCP). To review the defendant's claims, the court can set a hearing after three days. In this regard, to convince the court to issue a decision that will result in annulling or replacing the previous decision of the case, the defendant must provide reasonably available evidence. In the established judicial practice, at this stage, the court gives the opportunity to both parties to be heard and present sufficient evidence for granting security measures, (i.e., such evidence usually consists of a court judgment, direct examination, expertise, examination of witnesses, administrative decision, or contract, etc.) This reveals the temporary nature of interim measures as the court, when deciding either on annulment or replacement of the previous decision on interim measures, issues a new decision that sets security measures against which the unsatisfied party has the right to appeal. Finally, despite the fact that LCP entails only a single article regulating the interim measures in contrast to the

${ }^{1}$ Court decisions examined are those we had gathered from different courts, including first instance courts (basic courts); and second instance court (court of appeals). 
security measures that are included in dozens of articles, the civil courts have established to some extent a judicial practice that gives priority to an application for interim measures as an adequate legal instrument for protecting the rights and interests of the parties in civil proceedings. It is logical that an effective mechanism has to be in place and implemented promptly (Galič, 2014, p. 3) by the courts concerning protection of rights in civil litigation.

According to the LCP, the interim measures cannot include the entire request of the plaintiff pertaining to the value of that request (art. 300(3) LCP). Besides providing this prescription, the LCP has not enumerated any further circumstances that could be applied as such, but this has been more accurately established by the judicial practice. When deciding on a particular request for imposing an interim measure, a civil court may reject the request on the ground that the interim measures include the entire claim in terms of the value of such request. If a request for interim measures is in fact a request for an interim judgment, they should be denied because they could be seen to prejudice the decision on the merits and would be incompatible with provisions of the LPC and established judicial practice (Rieter, 2010, p. 42). Thus, the requirement of non-anticipation by one of the parties of a decision on the merits of the claim means that neither of the parties shall preempt the final determination of the case (Rieter, 2010, p. 42).

In this respect, civil courts have established some possible situations. First, the court cannot accept a request for interim measures which include the entire claim because the decision on interim measures would primarily decide one of the requests entailed in the claim. Second, granting an interim measure might be perceived as a partial decision on the merits of the claim. Third, such a decision would, to a great extent, prejudice a decision on the merits of the case (Case, C. No. 2405/12). Similar situations in practice would be, for instance, a conclusion by the court that the claim is identical to the request for imposing an interim measure in the same litigation.

\subsection{Security Measures Involving Claims for Securing the Rights and Preserving Existing Circumstances}

The LCP has provided that in proceedings involving claims for securing the rights and preserving existing circumstances, a number of interim measures can be imposed by the courts. Therefore, the court can set these measures, restraining the defendant from performing specified activities that could damage the plaintiff's position (art. 301(1)(a) LCP). In order to maintain the current situation in favor of plaintiff, the court alongside the measure that restrains the defendant from alienating a contested parcel of land, may set another measure forbidding the defendant from performing any activities that might change the factual situation with regard to the same parcel of land (Zogaj et al. 2019, p. 202). For instance, the court orders the defendant to cease his activities, (e.g., constructing, etc.) Another form of interim measure that court may impose, is directing the defendant to perform certain 
activities with regard to protecting of the plaintiff's property (art. 301(1)(b) LCP). Besides the measures above, it is possible for the court to appoint a trustee who will have the task of temporarily administering defendant's property (Westberg, 2012, p. 538). In this regard, the court may order the defendant to deposit a specified sum with a third-party trustee (OSCE, 2010) until the final decision on the case is rendered.

As was noted above, this group of measures provided in the provisions of the LCP, is not numerus clausus. If necessary, the civil courts may set other measures for securing the claim. In this case, the plaintiff may ask the court to forbid the alienation of certain property, reimburse the damage, or stop any other kind of action that would lead to the changing of factual situation. But, when seeking additional measures, the plaintiff must satisfy the legal requirements as set in the provisions of the LCP, by making his request reliable, and also arguing that acting otherwise would pose a danger of irreparable harm.

It is worth noting that in addition to the LCP, the interim (provisional) measures are enshrined in the provisions of the industrial property rights and copyright laws. Their main purpose is judicial protection of IP rights in civil litigation through imposing interim measures by terminating or preventing infringement of such rights (see art. 72, Law No. 05/L-058; art. 120, Law No. 04/L-029; art. 101, Law No. 04/L-026; and art. 185, Law No. 04/L-065). When there is a claim seeking judicial protection by litigants, courts apply the rules of contested procedure. Therefore, although these laws have special provisions for interim measures in IP cases (lex specialis) (Kamilovska, 2013, p. 5), the conditions and procedure for imposing such measures are specifically governed by the LCP as general law (lex generalis), (Case, Ae. No. 58/2018 and Case, Ae. No. 42/2018), that is applicable to all IP cases. For example, in a case involving infringement of a trademark, the court in addition to the legal requirements provided by the (lex specialis) (art. 101(1), Law No. 04/L-026), applies procedures and conditions set out in the LCP, specifically those provisions laid down in the art. 297. Thus, interim measures are the sole measures imposed by courts in IP cases due to their explicit enumeration in particular laws.

\section{Deposit as a Condition for Imposing Interim Measures}

Apart from the foregoing conditions, if the law does not determine otherwise, the court will grant interim measures only when the applicant (plaintiff) deposits a specific amount of money within the deadline set by the court. The main purpose of the deposit (guarantee) is to ensure compensation for any possible damages that the defendant may encounter during the litigation. Art. 297(2) of the LCP authorizes the court to set the deadline for lodging the deposit and the types of deposit as required in the LEP. Therefore, the LCP does not determine the amount of deposit, but this has been developed by the judicial practice to be an amount in proportion to the harm the defendant may suffer. The amount determined by the courts varies depending on a 
particular case, varying from $€ 5000$ to $€ 35.000,00$ or more (Case, C. No. 2658/10 and Case, C. No. 1881/11), and it should be paid on the account of the Kosovo Judicial Council in accordance with the provisions of the Law No. 06/L-055 on Kosovo Judicial Council. Since the deadline for lodging the deposit is not determined by law, it is prescribed by the court within seven days. However, prior to granting the interim measures, the court requires evidence establishing that the plaintiff has lodged the determined amount of guarantee. Such evidence must be presented within the deadline set by the court (Case, C. No. 1881/11).

As was noted above, however, the LCP does not enumerate forms of deposits that the court may order to provide adequate compensation for defendant. In this regard, it refers to the LEP, which designates the forms of guarantees that might be order as a condition for imposing interim measures. Primarily, deposits are given in cash, but the court, in accordance with LEP, may allow the deposit to be lodged in the form of (1) a bank guarantee; (2) securities; or (3) valuable items, the value of which is easily determined in the market and which may be liquidated quickly and simply (art. 14(1) LEP).

The question, however, is whether the application for interim measures will be granted if the applicant fails to lodge the deposit. In this case, both courts and the law agree that the application for granting interim measures should be rejected (Case, C. No. 550/11; see inter alia art. 297(3) LCP). Therefore, any failure of the plaintiff to provide sufficient evidence to the court that the deposit has been lodged within the deadline (seven days) set in advance by the court would lead to an inevitable rejection of the proposal. Even in these situations, however, the plaintiff is not fully deprived of his right to be granted interim measures as the legislature has foreseen a solution in this respect. For instance, due to the financial difficulties, the plaintiff might not be able to make the required deposit. As a result, he may seek a release from lodging the deposit, but he is obligated to support such a request. To make his request acceptable, the plaintiff must provide sufficient evidence regarding his financial difficulties, either by presenting a declaration of unemployment, (see also art. 3(1)(4), Law No. 05/L-077) or a certificate that proves that he is a social assistance beneficiary, etc.

The abovementioned are examples for rejecting the proposal for interim measures as a consequence of the plaintiff's failure to deposit the amount of deposit. In such cases, the court initially imposes the measure without receiving the deposit, and then acting upon the objection of the defendant against the decision on imposition of the interim measure, sets a hearing for granting of a security measure, and orders the plaintiff to deposit the amount. The plaintiff's failure to comply with the court order for lodging the deposit in order to impose the security measure, results in rejection of the proposal (Zogaj et al. 2019, p. 199). Finally, the amount of deposit given in accordance with the provisions of the LCP, will be return within seven days from the date the decision on interim measures has ceased (art. 298). It may be the case that the measures remain in force as the plaintiff files a lawsuit against the defendant for compensation of damages. In this situation, the competent court for deciding the case involving 
the claim for compensation of damage will decide whether the interim measures will remain in force until the final decision on the case is reached.

\section{Unjustified Measures and the Right to Compensation}

As we have already indicated, the aim of the interim measures is to preserve the rights and interests of the parties in civil litigation. More specifically, the purpose of the use of interim measures is to safeguard the rights of each party (Rieter, 2010, p. 39), and also to preserve the court's ability to render a meaningful judgment (Wong, 2005, p. 607) in the dispute. Each party is entitled to seek protection of his rights if the other party acts contrary to the court decision on granting interim measures. The LCP has set out the rules for liability in cases when the defendant acts against the court order that forbids the alienation, hiding, indebting or disposing the property. The rules for civil liability will be accordingly applied (art. 302(1) LCP). Consequently, the actions taken by the defendant that lead to the alienation, hiding, indebting or disposing the property have no effect over the plaintiff (art. 302(2) LCP). The plaintiff has the right to be compensated in accordance with the rules pertaining to reimbursement for material damage (see art. 315(1) LCP). At the domestic level, these rules are included in the provisions of the Law on Obligational Relationships (Official Gazette, No. 16/19 June 2012) (henceforth "LOR").

According to the provisions of the LOR, damage may be compensated in one of the following ways: (1) restitutio in integrum; or (2) monetary compensation. Through the restitutio in integrum the liable person (defendant) is obliged to reestablish the situation prior to the occurrence of the damage. Accordingly, if through the reestablishment of the previous situation, the damage is not entirely rectified, the liable person will be obliged to pay monetary compensation to the plaintiff (art. 169 (1)(2) LOR). Likewise, the monetary compensation will be considered when the reestablishment of the previous situation is impossible and the court considers such action no longer necessary. Besides the monetary compensation, the plaintiff is entitled to reimbursement of lost profit (art. 173(1) LOR). So far, we have given due consideration to the liability of the defendant for acting in contradiction to the court decision, and also the right of the plaintiff to be compensated in case of any damage inflicted by the defendant.

However, the LCP recognizes the right of the defendant to be compensated as well. The defendant has a right of appropriate compensation for injury caused by interim measures that were: (1) unfounded; or (2) not justified (art. 316 LCP). When the interim measure has been imposed against the defendant forbidding the alienation, hiding, and indebting or disposing the property, damages will be awarded if such measures turns out to be unfounded. The defendant can exercise his right for compensation as a result of unfounded measures in a separate civil proceeding (contested procedure). If damage incurs as a result of unjustified measures, the defendant may invoke his right to compensation. For instance, an unjustified measure would be in cases where the measure has been imposed in absence of evidence. The plaintiff is required 
to provide reasonably available evidence in order to satisfy the court with a sufficient degree of certainty with regard to the plausibility of his request and also his contention that there is a risk that the defendant will make it impossible or difficult to implement the request for the interim measure. The defendant is entitled to the same rules mentioned above concerning his right to request compensation for damage. Finally, the request for compensation of damages, whether submitted by the plaintiff or defendant, expires within a year from the day the decision on interim measures ceases (art. 317 LCP).

\section{Stages of Procedure and the Time Limit for Filing the Proposal}

The request for granting security measures may be lodged in various stages of a procedure. According to the LCP, the proposal for security measures can be lodged prior to filing the claim (before commencing the main proceedings), during the proceedings and after finalization of proceedings, until the enforcement is fully carried out (art. 304(1). The competence to decide over the proposal filed before and during the commencement of the main proceedings is the court that acts according to the claim, which means the first instance court (basic court). However, if the proposal is lodged after filing the complaint to the higher court, the competence to decide over that proposal is accorded to the second instance court (court of appeals). The opportunity of granting the proposal on security measures before commencing the main proceedings is possible only if there a serious risk concerning the realization of the plaintiff's claim. When imposing such measure, the court in its decision will set a time limit of no less than thirty days for the plaintiff to file the claim. To do so, the plaintiff must present the facts to the court that are deemed to justify the request for granting the measure (art. 308(1)(2) LCP).

The LCP, does not however provide the opportunity of imposing interim measures before commencing the main proceedings. The possibility of granting only the security measures (Zogaj et al. 2019, p. 207) is foreseen in the provisions of the Articles 296, 304 and 308 of the LCP. The interim measures in this stage are excluded. We have argued elsewhere, that the interim measures are usually imposed without giving the defendant an opportunity to express his opinion or providing the evidence (ex parte), whereas in case there is a proposal for granting the security measures before commencing the proceedings, the court sets out the hearing giving both parties the opportunity to express their opinions over the proposal (inter partes). In unpublished cases we have examined, the most frequent type of proposal is that submitted in the course of the main proceedings. Two different ways for submitting the proposal are available. Usually the proposal is submitted in writing, but if the proposal is related to the ongoing proceedings it can be presented orally in the court hearings (art. 304(2) LCP). The proposal, in its content, should include some necessary elements such as the request for a measure required by the proposal, type of measure, and the means and object of the measure. Additionally, the proposal should indicate the facts that the claim is based on, as well as propose evidence which could prove pretension, already included in the proposal (art. 
304(3) LCP). The LCP does not set out the time limit for granting the security measures (Kamilovska, 2013, p. 12.), but considering their urgent nature aimed at protecting the rights and interest of the parties involved in civil litigation, the courts should act in the same fashion by examining the proposal without delay.

\section{Legal Remedies}

The procedure for legal remedies is laid down in the LCP stipulates two kinds of remedies: (1) the appeal, and (2) the objection. In the procedure for granting security measures, the right to appeal is the remedy parties can seek with the court within seven days. When the decision on interim measures is issued, the defendant is entitled to reply by filing an objection to the court within three days (art. 310(1) and 306(2) LCP). There is an explicit provision in the LCP that prohibits the appeal as a legal remedy against a decision granting an interim measure (art. 310(5), but it is allowed (the appeal) against a decision on security measure within seven days from the day the decision is served. In practice, it is frequently the case that the courts have allowed the appeal against the decision on interim measures when the courts have found the original request unfounded (Case, C. No. 550/11; Case, C. No. 1715/12).

The courts reject a proposal for security measures when a party fails to fulfill the legal conditions provided for in the LCP. If the court rejects the proposal, the plaintiff has the right to appeal the decision within fifteen days from the day of service of the copy of the decision. In this regard, there is a difference of opinion within the judiciary over the right to appeal a decision on interim measures. Some judges have supported recognizing the right of appeal, whilst another group disagrees with the idea of providing such right. The first position supporting the right to appeal was reasoned through a dissenting opinion of the Court of Appeals (Ac. No. 4778/15, dt. 12.01.2016). According to the dissent, the prohibition of the right to appeal leads to departure of the court from its established judicial practice, and violates the provisions of the Constitution of the Republic of Kosovo (henceforth: "CRK"). Additionally, the dissent claims that the court of appeals, when dealing with appeals against the decisions on interim measures issued by lower courts, has not rejected them as inadmissible, but has decided on the merits over the appeals. Therefore, granting the right to appeal in such cases is a prerequisite for realization of the contradictory principle. The latter position is supported by a recent court of appeals' standing establishing that, in cases of rejection of a proposal for imposing interim measures as unfounded, the right of appeal is not permitted. A court of appeals' judge admits that in previous judicial practice, when the proposal for granting interim measures has been rejected, the right to appeal was granted, whereas according to the recent standing of the court of appeals, the right to appeal is not allowed, however, if such proposal for imposing interim measures is approved, the objection is permitted as a legal remedy.

It is accepted in domestic legal systems, and by international standards for human rights (art. 6. ECHR, 1950) that the right to appeal is a basic human right. According to Articles 32 and 102(5) of the CRK, the right to appeal a 
judicial decision is guaranteed. If we examine more closely the content of art. 310(5) LCP, it is obvious that the plaintiff does not have the right to appeal the decision on interim measures, but such a position is incompatible with constitutional guarantees, and violates basic principle of audiatur at altera pars. Pursuant to this principle of contradiction (Samuel, 2016, p. 316), it is well known that the court must allow parties to give their statements about the claims and declarations of the opposite party in civil litigation (Ivanc, 2015, p. 11). Likewise, art. 5(1) LCP, regulates this principle, which provides that the court shall enable each party to make a statement on the claims and allegations submitted by the opposite party. Rather, the principle of hearing from both parties appears not only to enable the parties to participate in litigation, but also activates the parties to take their actions in civil proceedings (Kramar, 2015, p. 10). Recent judicial practice tends to see courts dismissing the appeal against the decision on interim measures as inadmissible (Zogaj et al. 2019, p. 208), which is not in line with the previous established judicial practice.

Prior judicial practice, saw the court of second instance rejecting the appeal against the decision on interim measures only when there had been sufficient grounds to conclude that the appeal was unfounded (Case, Ac. No. 98/14). The court of appeals has followed that practice by rejecting the appeal as unfounded and affirming the decision of the court of first instance, but did not reject the appeal against the decision on interim measures as inadmissible without sufficient grounds (Case, Ac. No. 3180/14). So, the court of first instance has granted the plaintiff the right to appeal the decision and proceed with the case further to the second instance court. However, if the appeal against the decision on interim measures issued by the court of first instance is not allowed (inadmissible) this will result in a deprivation of the plaintiff's rights which is not the case with a defendant who has the right to file an objection with the court within three days from the day the copy of decision is served (see art. 306(2) LCP). The departure from previous practice (i.e., now prohibiting the appeal) infringes upon the principle of audiatur at altera pars in a way that deprives the plaintiff of his right to challenge claims and statements presented by the opposite party (defendant).

As has been noted, the right to appeal the decision on interim measures has been recognized by previous judicial practice. This distinction separates the security measures from interim measures in civil proceedings. It appears that the courts of first instance are adhering to art. 310(5) LCP, which means they are legally obliged to ex officio dismiss the appeal against the decision on interim measure as inadmissible. Under this practice, although the courts of first instance are obliged to dismiss the appeal as inadmissible, in fact they are allowing the appeal against the decision on interim measures. Despite this, the court of appeals acts by dismissing the appeal as inadmissible regardless of the lower courts position (Case, Ac. No. 4696/17).

We have noted earlier, that the interim measures are ordered ex parte, which inevitably leads to an ex parte discussion of the merits and context of the case. Hence, they appear to infringe the principle of hearing from both parties, since one party is allowed to address the court without the other party knowing 
about it (Savola, 2016, p. 80). Considering these factors, the right to appeal should be considered against a decision on interim measures in order to provide a party with a level of legal certainty and also to satisfy the constitutional guarantees and international human rights standards that expressly embraces the right to legal remedies as a basic human right.

\section{Conclusion}

The imposition of interim measures in civil proceedings remain an important legal mechanism for preserving the rights and interests of litigants, and accelerating the process toward a final judgment on the case. These measures are used to secure claims involving either property disputes or intellectual property rights. The analysis above, has shown some problems with regard to the application of these measures. The courts usually consider certain criteria, circumstances and elements while reviewing the application for granting interim measures. Although they bear common characteristics, when it comes to the application, courts tend to give priority to one group over the other.

In judicial practice, courts frequently use interim measures rather than security measures. The courts act promptly and diligently in order to restrain the defendant from alienating, hiding, encumbering or disposing the plaintiff's assets until the final judgment on the merits of the case is rendered. At this point, they usually consider two elements: urgency and plausibility of the matter. The plaintiff must provide reasonably available evidence to the court that his rights are being infringed, or that such infringement is imminent.

With regard to the application of legal remedies, however, there is a contradiction among the judiciary over the right to appeal the decision on interim measures. Some support the idea of right to appeal, whilst the others do not. Due to this inconsistency, the court of appeals has reached an official standing establishing that, in case of a decision on interim measures, the right to appeal is not permitted. From the perspective of legal certainty, such a position leads to incompatibility with constitutional guarantees, and violates basic principle of audiatur at altera pars. Allowing of the right to appeal would to a great extent strengthen with the principal of legal certainty and also to satisfy the constitutional guarantees and international human rights standards that recognize such a right. 


\section{Bibliography}

\section{Books and articles}

Samuel, G. (2016). Epistemology and Method in Law, Routledge, Taylor \& Francis Group, London and New York.

Westberg, P. (2012). Interim Measures and Civil Litigation, Scandinavian Studies in Law. Retrieved January 6, 2020, from: http://www.scandinavianlaw.se/pdf/51-25.pdf

Atlihan, Ö. (2011). The Main Principals Governing Interim Measures in the Pre-arbitral Proceedings - Specifically, the ICC Emergency Arbitrator Rules, Annales XLIII, N. 60, 203-262, 2011. Retrieved January 15, 2020, from: https://dergipark.org.tr/download/article-file/7029

Morina, I. \& Nikçi, S. (2012). Komentar i Ligjit për Proceduren Kontestimore, [Commentary of the Law on Contested Procedure], GIZ, Vol. I.

Friedenthal, J, H., Miller, A, R., Sexton, J, E., \& Hershkoff, H. (2013). Civil Procedure, Cases and Materials, $11^{\text {th }}$ ed., American Casebook Series, West Academic Publishing.

Kamilovska - Zoroska, T. (2013). Interim measures in IP litigation from the Macedonian perspective, Iustinianus Primus Law Review Volume, 4 (1). Retrieved February 2, 2020, from: https://www.internationalarbitration-attorney.com/wp-content/uploads/1 tatjana-zoroskakamilovska-ph-d-ef-80-aainterim-measures-in-ip-litigationfrom-themacedonian-persp.pdf

Galič. A. (2014). Public and Private Justice, Procedural Human Rights and Access to Justice in the World of Emergencies and Economic Crises, PPJ Course and Conference, IUC Dubrovnik, 26-30 May. Retrieved January $8, \quad 2020$, from: http://www.alanuzelac.from.hr/iuc/course2014/PPJ_2014_course_mat erial.pdf

Savola. M. (2016). Interim Measures and Emergency Arbitrator Proceedings, Croat. Arbit. Yearb. Vol. 23, UDK: 347.918:347.937. Retrieved February 20, 2020, from: https://www.hannessnellman.com/sites/default/files/savola_cay_23.pd $\mathrm{f}$

Rieter, R., E. (2010). Preventing Irreparable Harm. Provisional Measures in International Human Rights Adjudication, Stichting Internationale Informatie en Communicatie, J.E. Jurriaanse Stichting and Maastricht University, Intersentia, 978-90-5095-931-5. Retrieved March 5, 2020, from: http://www.corteidh.or.cr/tablas/r23872.pdf

Zogaj, A., Leku, Z., Totaj, V., Hasanpapaj, B., \& Cunniff, A., M. (2019) Manual për Zbatim të Procedurës Kontestimore, [Manual for Application of Contested Procedure], USAID. Retrieved January 17, 2020, from: http://www.gjyqesori-rks.org/wpcontent/uploads/reports/72001_MANUAL_PER_ZBATIM_TE_PRO CEDURES_KONTESTIMORE.pdf 
Wong, J. (2005). The Issuance of Interim Measures in International Disputes: A Proposal Requiring a Reasonable Possibility of Success on the Underlying Merits, GA. J. INT'L \& COMP. L. Vol. 33: 605. Retrieved March 8, 2020, from: https://digitalcommons.law.uga.edu/cgi/viewcontent.cgi?referer=https $: / /$ www.google.com/\&httpsredir=1\&article=1358\&context=gjicl

Ivanc, T. (2015) Evidence in Civil Law, Slovenia, Institute for Local SelfGovernment and Public Procurement Maribor, Lex Localis, Book series Law \& society, ISBN 978-961-6842-58-7, 347(497.4)(0.034.2). Retrieved April 22, 2020, from: http://www.lexlocalis.press/index.php/LexLocalisPress/catalog/book/32

Kramar, A., S. (2015). Evidence in Civil Law, Croatia, Institute for Local SelfGovernment and Public Procurement Maribor, Lex Localis, Book series Law \& society, ISBN 978-961-6842-40-2, 347(474)(0.034.2). Retrieved April 23, 2020, from: http://www.lexlocalis.press/index.php/LexLocalisPress/catalog/book/23

Organization for Security and Co-operation in Europe, Use of Interim Measures in Civil Proceedings in Kosovo, LSMS Issue 11 (2010), pp. 1-3. Retrieved April 5, 2020, from: https://www.osce.org/kosovo/74879?download=true

\section{Legislation and legal documents}

Constitution of the Republic of Kosovo. Retrieved May 3, 2020, from: http://www.kryeministriks.net/repository/docs/Constitution1Kosovo.pdf

European Convention on Human Rights, [Right to a Fair Trial]. Retrieved May 5, 2020, from: https://www.echr.coe.int/Documents/Convention_ENG.pdf

Law No. 03/L-006 on Contested Procedure, Official Gazette of the Republic of Kosova/Pristina: Year III/No. 38/20 September 2008. Retrieved January 23, 2020, from: https://gzk.rksgov.net/ActDetail.aspx?ActID=2583

Law No. 03/L-008 on Executive Procedure, Official Gazette of the Republic of Kosova/Pristina: Year III/No. 33/15 July 2008. Retrieved February 24, 2020, from: https://gzk.rks-gov.net/ActDetail.aspx?ActID=2870

Law No. 04/L139 on Enforcement Procedure, Official Gazette of the Republic of Kosova/No. 3/31 January 2013, Pristina. Retrieved March 2, 2020, from: https://gzk.rksgov.net/ActDetail.aspx?ActID $=2870$

Law No. 05/L -058 on Industrial Design, Official Gazette of the Republic of Kosova/No. 40/31 December 2015, Pristina. Retrieved April 10, 2020, from: https://mti.rks-gov.net/desk/inc/media/3D49821C0CFE-4A11-B8CB-EA208E426D75.pdf 
Law No. 04/L-029 on Patents, Official Gazette of the Republic of Kosova/No. 12/29 August 2011, Pristina, Retrieved April 11, 2020, https://gzk.rks-gov.net/ActDetail.aspx?ActID=2756

Law No. 04/L-026 on Trademarks, Official Gazette of the Republic of Kosova/No. 10/24 August 2011, Pristina. Retrieved May 3, 2020, from: https://gzk.rks-gov.net/ActDetail.aspx?ActID=2753

Law No. 04/L-065 on Copyright and Related Rights, Official Gazette of the Republic of Kosova/No. 27/30 November 2011, Pristina. Retrieved May 20, 2020, from: https://gzk.rksgov.net/ActDetail.aspx?ActID $=2445$

Law No. 06/-055 on Kosovo Judicial Council, Official Gazette of the Republic of Kosovo, No. 23/26 December 2018, Pristina. Retrieved May 13, 2020, from: https://gzk.rks-gov.net/ActDetail.aspx?ActID=2713

Law No. 05/L-077 on Registration and Providing of the Services for Unemployed, Jobseekers and Employers, Official Gazette of the Republic of Kosovo, No. 26/21 July 2016, Pristina. Retrieved April 20, 2020, from: https://gzk.rks-gov.net/ActDetail.aspx?ActID=2817

Law No. 04/L-077 on Obligational Relationships, Official Gazette of the Republic of Kosova, No. 16/19 June 2012, Pristina. Retrieved June 3, 2020, from: https://gzk.rks-gov.net/ActDetail.aspx?ActID=2828

\section{Cases}

Case, C. No. 228/13, date 27.05.2013, Basic Court in Pristina.

Case, C. No. 3280/13, date 16.01.2014, Basic Court in Pristina.

Case, C. No. 550/11, date 03.01.2013, Basic Court in Peja

Case, C. No. 1715/12, date 27.05.2015, Basic Court in Pristina.

Case, C. No. 675/12, date 28.05.2012, Basic Court in Pristina.

Case, C. No. 2405/12, date 31.07.2012, Basic Court in Pristina.

Case, C. No. 2658/10, date 07.05.2015, Basic Court in Pristina.

Case, C. No. 1881/11, date 27.05.2015, Basic Court in Pristina.

Case, Ae. No. 58/2018, Court of Appeals.

Case, Ae. No. 42/2018, date 09.02.2018, Court of Appeals

Case, Ac. No. 98/14, date 16.05.2014, Court of Appeals.

Case, Ac. No. 3180/14, date 16.12.2014, Court of Appeals.

Case, Ac. No. 4696/17, date 06.12.2017, Court of Appeals. 
